friends, they had planned to celebrate their fiftieth wedding anniversary in December 2008.

\author{
Russ ZGuTA \\ University of Missouri \\ April 2008
}

\title{
Josephine Woll, 1950-2008
}

Josephine Woll, Josie to her many friends, died on 12 March 2008 just a few days before her fifty-eighth birthday. In the course of her long illness she had endured numerous bouts of chemotherapy with exceptional fortitude.

Josie grew up in the Bronx, the youngest of three sisters, and a member of a closeknit Jewish family. In public school, Josie skipped two years, so she entered William Smith College in Geneva, New York, at age 16 and graduated in 1970 with a major in comparative literature. She attended graduate school at the University of North Carolina, Chapel Hill, and received her $\mathrm{PhD}$ in Russian language and literature, writing her dissertation on Aleksandr Pushkin. After teaching briefly at Duke University, she moved to Washington, D.C., in 1977 and began working at Howard University, where she spent the remainder of her academic career.

In 1977, Josie married Abraham Brumberg, a scholar, journalist, and former editor of Problems of Communism. They lived together happily for thirty-one years until Abe's recent death. Both of them were sociable people, and they had a large circle of friends. In Chevy Chase they maintained what can best be described as an intellectual salon. With their wit and broad interests, they had a remarkable talent for bringing people together, and evenings at their home were always pleasant and stimulating. (In addition to her other talents Josie was an excellent cook.)

Josie's exceptionally wide interests were well reflected in her scholarship. Her first published work was an annotated bibliography of Soviet samizdat literature that she and Vladimir G. Treml brought out in 1978 (and republished in an expanded form in 1983): Soviet Dissident Literature: A Critical Guide. In 1991 she published Invented Truth, a study of the writings of Iurii Trifonov, arguably the best writer of the late Soviet period. A sophisticated critic with an excellent knowledge of Soviet reality, Josie demonstrated Trifonov's adroit strategy for expressing heterodox thoughts at a time of strict censorship. From reading her book, one learns that Trifonov was not only a critic of the Soviet world in which he lived and of his nation's bitter and bloody past but also a skilled writer whose work has remained interesting even decades after the passing of the Soviet state.

Josie later became interested in Soviet film and, in 2000, published Real Images; Soviet Cinema and the Thaw. Just like her work on Trifonov, this book reflects the duality of her interests. On the one hand the book is a contribution to our knowledge of this remarkable period of Soviet history, but on the other it is a work from which the reader can gain an understanding of the artistic quality of the films that she discussed. Josie continued to publish widely on Soviet cinema, writing reviews and articles. She also wrote two volumes in the Tauris "film companion series," one on the Cranes Are Flying (2003) and the other on Repentance (2001, written together with her friend, Denise Youngblood).

Josie also had an abiding interest in the history of Russian and Soviet Jewry, and she published reviews and articles on this topic. The knowledge of Yiddish that she had acquired as a girl was put to good use.

Those of us who had the good fortune to know Josie well remember her as a woman of great warmth and strength, someone with a talent for friendship, and altogether the best human being among our friends. We miss her terribly.

Peter Kenez

University of California, Santa Cruz April 2008 